\author{
WOJCIECH SOSNOWSKI ${ }^{1, A}$, VIOLETTA KOSESKA-TOSZEWA ${ }^{1, B}, \&$ ANNA KISIEL $^{2, C}$ \\ ${ }^{1}$ Institute of Slavic Studies, Polish Academy of Sciences, Warsaw, Poland \\ ${ }^{2} \mathrm{KU}$ Leuven, Leuven, Belgium \\ ${ }^{A}$ wpsosnow@uw.edu.pl ; ${ }^{B}$ amaz@inetia.pl ; ${ }^{C}$ anna.kisiel@kuleuven.be
}

\title{
ON THE DICTIONARY OF SEMANTIC EQUIVALENTS IN POLISH, BULGARIAN AND RUSSIAN
}

\begin{abstract}
Leksykon odpowiedniości semantycznych w języku polskim, bułgarskim i rosyjskim [The Dictionary of Semantic Equivalents in Polish, Bulgarian and Russian] is the first Polish dictionary which compares semantic equivalents in the largest languages of each Slavic subgroup: The West Slavic group (Polish), the South Slavic group (Bulgarian) and the East Slavic group (Russian). The content of the dictionary reflects the social processes, changes and trends which have taken place over recent years. The dictionary consists of 5 volumes, with approximately 5000 entries for each language. What sets it apart from other dictionaries is that it ventures beyond the standard vocabulary one might expect from a dictionary of this sort. Leksykon... also contains neologisms as well as realogisms - words which do not often have perfect equivalents in other languages because they are so deeply embedded in a nation's culture. Each entry in the dictionary offers state-of-the-art semantic and syntactic categorisers, developed by Polish experts in Slavic semantics and aspectology.

We consider the dictionary to be an innovation in lexicography, because its open structure enables more languages to be added in the future, including non-Slavic languages. Developed with the use of the most recent methodologies available, the dictionary will constitute a sound basis for lexicographic research in the future, in particular for the development of multilingual electronic dictionaries.

In the $21^{\text {st }}$ century, we face two great challenges: to make academic research more interdisciplinary and to build an integrated multinational European community. We hope that our dictionary will help address these challenges by promoting multilingualism and facilitating intercultural communication. The primary language of the dictionary is Polish - the largest Slavic language in the European Union.

During the Polish presidency of the EU, a conference entitled Multilingual Competences for Professional and Social Success in Europe was held. It concluded with the following declaration: "Multilingualism is not only part of European heritage, but also a chance to develop a society which is open, respectful of cultural diversity and ready for cooperation". However, the chief obstacles that prevents the EU from attaining the full integration of its economies and societies are language barriers. This dictionary will help overcome these barriers by promoting Slavic languages. The target audience of the dictionary are speakers of Polish, both in Poland and all around the world: experts in Slavic languages, scholars, lexicographers, encyclopaedia writers, students, etc.
\end{abstract}

Keywords: dictionary; multilingualism; semantic labels; syntactic labels; net model of time 


\section{Multilingualism}

The dictionary described in this paper contains entries in three Slavic languages: Russian, Bulgarian and Polish. The main purpose of the dictionary is to show semantic equivalents between words and phrases in these languages. Each entry consists of three columns - one for each language. The equivalents are aligned horizontally, so that the equivalents of a source word in one language appear in the same line, as in the example below:

Table 1:

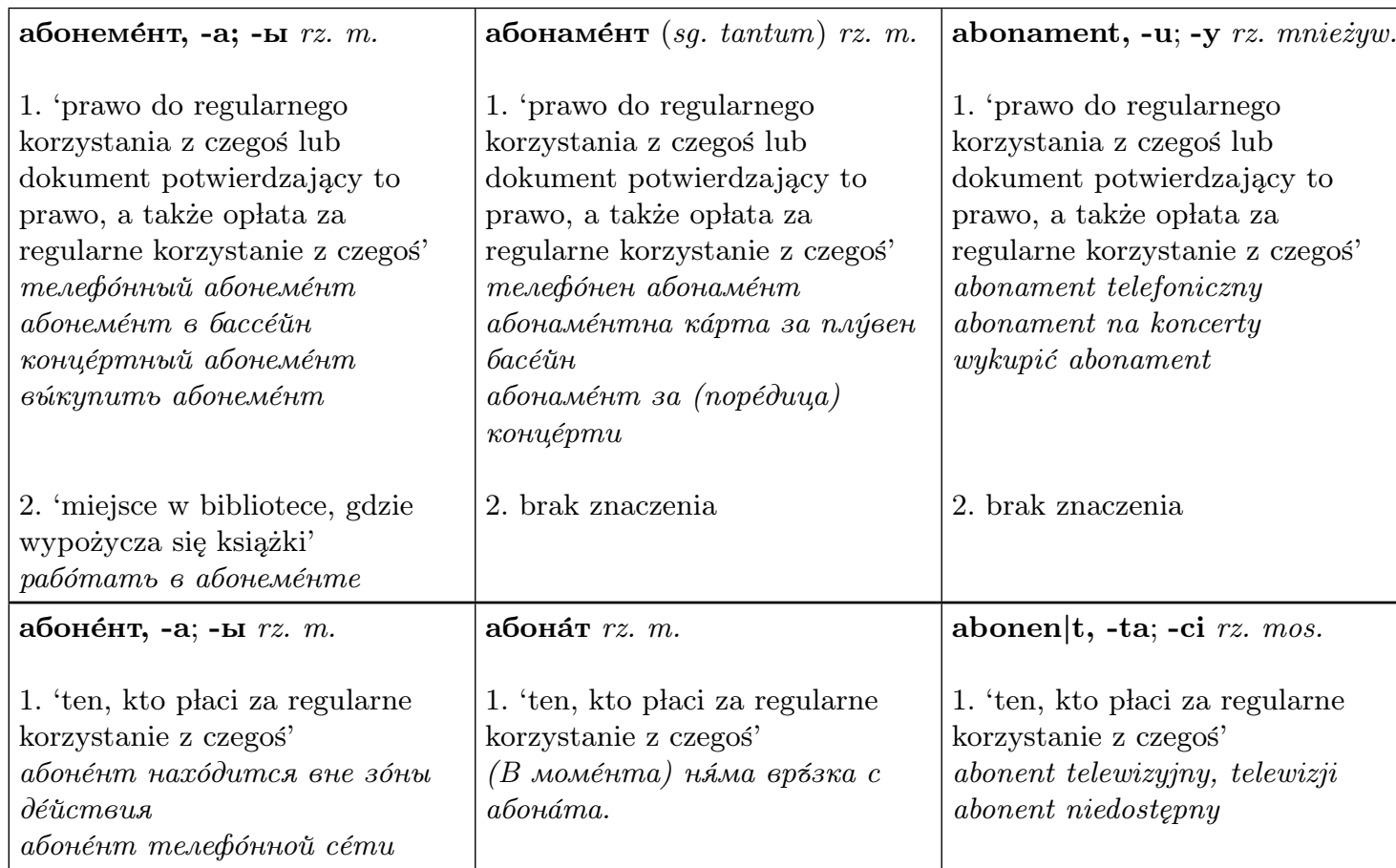

1.1 Work on the dictionary was based on a number of various data sources: written and spoken texts, our own research experience as well as many inspiring papers and monographs, which are listed in the bibliography. The structure and the contents of the dictionary reflect the changes Slavic languages have undergone recently, e.g. the Russian word апартамент / апартаменты, which is currently used in both the plural and singular form, whereas previous dictionaries only listed the plural form as correct.

1.2 The dictionary consists of 5 volumes (or 10 sub-volumes). The first volume contains around 1000 entries in one language (letters $\mathrm{A}-\mathrm{E}$ in the Cyrillic alphabet).

1.3 Examples come from the National Corpus of Polish, the Polish-Bulgarian Parallel Corpus (Dimitrova, Koseska-Toszewa) and the Polish-Bulgarian-Russian Parallel Corpus (KoseskaToszewa, Satoła-Staśkowiak, Sosnowski, \& Kisiel). The dictionary does not contain all the lexis available in the languages. A decision had to be made over which lexemes to include, and this was done on the criterion of frequency.

\section{Structure of entries}

The principle that guided the development of the dictionary was that all the languages should enjoy equal status. Nevertheless, a decision needed to be taken as to which alphabet was to be used 
to sort the entries. Neither the Cyrillic nor the Latin alphabet has any substantial advantages over the other, so it was an arbitrary choice. In the end, it was decided to sort the entries according to the Cyrillic script, in the order the words appear in Russian.

2.1 Different meanings of homonyms are indicated with Roman numerals:

Table 2:

\begin{tabular}{|c|c|c|}
\hline $\begin{array}{l}\text { ë̈ I forma } B ., D . \text { zaimka } \\
\text { osobowegо она }\end{array}$ & $\begin{array}{l}\text { (на) не́я forma zaimka } \\
\text { osobowego } m я\end{array}$ & $\begin{array}{l}\text { jej I forma } D \text {. zaimka osobowego } \\
\text { ona }\end{array}$ \\
\hline $\begin{array}{l}\text { 'wyraz wskazujący na obiekt } \\
\text { (osobę, zwierzę, przedmiot, } \\
\text { wydarzenie - rodzaju } \\
\text { żeńskiego), o którym mówimy' } \\
\text { Я ё̈ вчерá не ви́дел. }\end{array}$ & $\begin{array}{l}\text { 'wyraz wskazujący na obiekt } \\
\text { (osobę, zwierzę, przedmiot, } \\
\text { wydarzenie - rodzaju } \\
\text { żeńskiego), o którym mówimy' } \\
\text { Вчépa не́я не съм я ви́љдал. } \\
\text { Дай квита́нцията на не́я, a } \\
\text { nари́те скри́й в шка́фа! }\end{array}$ & $\begin{array}{l}\text { 'wyraz wskazujący na obiekt } \\
\text { (osobę, zwierzę, przedmiot, } \\
\text { wydarzenie - rodzaju } \\
\text { żeńskiego), o którym mówimy' } \\
\text { Nie widziatem jej wczoraj. }\end{array}$ \\
\hline $\begin{array}{l}\text { eё II }(n d m) \text { zaimek dzierżawczy } \\
r . \dot{z} .\end{array}$ & не́ин, и́ zaimek dzierżawczy r. $\dot{z}$. & $\begin{array}{l}\text { jej II }(n d m) \text { zaimek dzierżawczy } \\
r . \dot{z} .\end{array}$ \\
\hline $\begin{array}{l}\text { 1. 'to, o czym mowa, należy do } \\
\text { czegoś (do jakiejś osoby, } \\
\text { przedmiotu, zjawiska itd. - } \\
\text { rodzaju żeńskiego)' } \\
\text { ё мamъ }\end{array}$ & $\begin{array}{l}\text { 1. 'to, o czym mowa, należy do } \\
\text { czegoś (do jakiejś osoby, } \\
\text { przedmiotu, zjawiska itd. - } \\
\text { rodzaju żeńskiego)' } \\
\text { нéŭнama мáŭкa; мáŭкa ú }\end{array}$ & $\begin{array}{l}\text { 1. 'to, o czym mowa, należy do } \\
\text { czegoś (do jakiejś osoby, } \\
\text { przedmiotu, zjawiska itd. - } \\
\text { rodzaju żeńskiego)' } \\
\text { jej matka }\end{array}$ \\
\hline $\begin{array}{l}\text { 2. 'używane przy zwracaniu się } \\
\text { do osoby o wysokim stanowisku } \\
\text { lub tytule' } \\
\text { Её короле́вское вели́чество }\end{array}$ & $\begin{array}{l}\text { 2. 'używane przy zwracaniu się } \\
\text { do osoby o wysokim stanowisku } \\
\text { lub tytule' } \\
\text { Не́ŭно вели́чество }\end{array}$ & $\begin{array}{l}\text { 2. 'używane przy zwracaniu się } \\
\text { do osoby o wysokim stanowisku } \\
\text { lub tytule' } \\
\text { Jej Królewska Mość }\end{array}$ \\
\hline brak znaczenia & brak znaczenia & $\begin{array}{l}\text { jej III wykrzyknik } \\
\text { 'wyraz wskazujący na } \\
\text { nieoczekiwaność danej emocji' } \\
\text { O jej, ale mnie wystraszyteś! } \\
\text { Jej, już nie mogę...! }\end{array}$ \\
\hline
\end{tabular}

2.2 Consequently, if a verb has a single phonetic realisation of two different aspects, it is treated as homonymous:

Table 3:

\begin{tabular}{|c|c|c|}
\hline $\begin{array}{l}\text { аренд|ова́ть, -у́ю, -у́ешь I vi. } \\
\text { state, transitive }\end{array}$ & $\begin{array}{l}\text { да взе́ма|м под на́ем fraza } \\
\text { werbalna lub да нае́ма|м } \\
\text { не́що fraza werbalna }\end{array}$ & $\begin{array}{l}\text { dzierżaw|íć, -ię, -isz vi. state, } \\
\text { transitive }\end{array}$ \\
\hline $\begin{array}{l}\text { 1.'mieć coś w dzierżawie' } \\
\text { арендова́тъ зе́млю у сосе́да }\end{array}$ & $\begin{array}{l}\text { 1. 'mieć coś w dzierżawie' } \\
\text { да нае́мам земя́ / да взе́мам } \\
\text { земя́ под на́ем }\end{array}$ & $\begin{array}{l}\text { 1. 'mieć coś w dzierżawie' } \\
\text { dzierżawić ziemię od sasiada }\end{array}$ \\
\hline $\begin{array}{l}\text { 2.'mieć coś oddane w dzierżawę' } \\
\text { арендова́mъ nóле сосе́dy }\end{array}$ & $\begin{array}{l}\text { 2. 'mieć coś oddane w dzierżawę' } \\
\text { Нае́мам ни́ва на съсе́да си }\end{array}$ & $\begin{array}{l}\text { 2. 'oddawać coś w dzierżawę' } \\
\text { dzierżawić pole sasiadowi }\end{array}$ \\
\hline
\end{tabular}




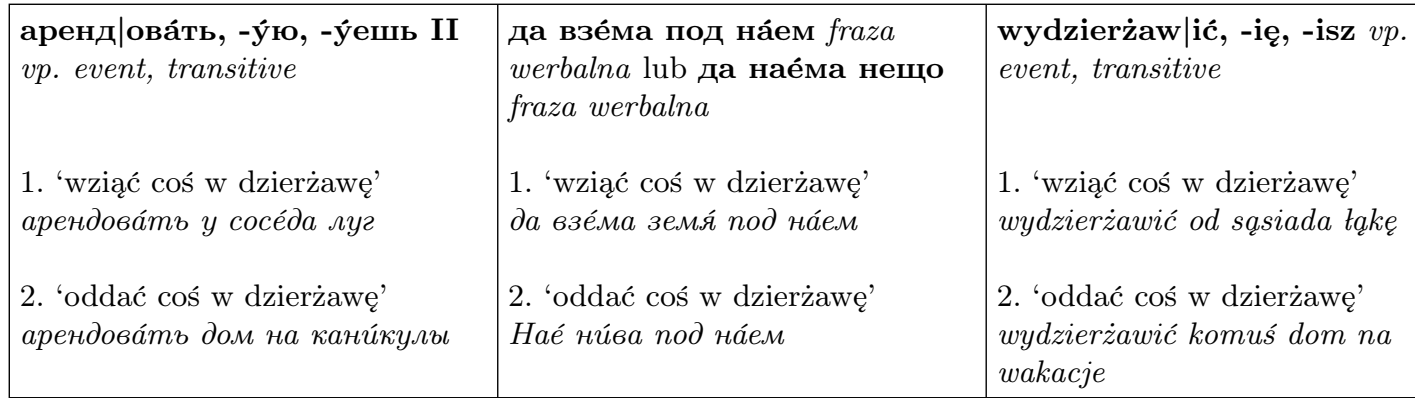

It would be undesirable for a verb to be treated both as perfective and imperfective, e.g. арендова́mъ vi., vp.

For Russian and Bulgarian - which have variable word stress - the word stress was marked both in the lemma, as well as in the examples:

Table 4:

\begin{tabular}{|c|c|c|}
\hline 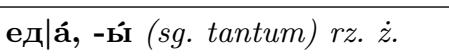 & $\mathbf{x р а н | a ́ , ~ - и ~} r z . \dot{z}$. & jedzeni|e, -a (sg. tantum) rz. $n$. \\
\hline $\begin{array}{l}\text { 1. 'to, co można jeść' } \\
\text { вку́сная, изъ́ссканная еда́ } \\
\text { гото́вить еду́ }\end{array}$ & $\begin{array}{l}\text { 1. 'to, co można jeść' } \\
\text { вку́сна хранá } \\
\text { Приго́твям храна́ за бо́лния. }\end{array}$ & $\begin{array}{l}\text { 1. 'to, co można jeść' } \\
\text { pyszne, wykwintne jedzenie } \\
\text { przyrzadzać, szykować, } \\
\text { przygotowywać jedzenie }\end{array}$ \\
\hline $\begin{array}{l}\text { 2.'przyjmowanie posiłku' } \\
\text { принима́mъ лека́рство до едъ́ }\end{array}$ & $\begin{array}{l}\text { 2. 'przyjmowanie posiłku' } \\
\text { Взе́мам това́ лека́рство преди́ } \\
\text { я́дене. }\end{array}$ & $\begin{array}{l}\text { 2. 'przyjmowanie posiłku' } \\
\text { wziacć lekarstwo przed jedzeniem }\end{array}$ \\
\hline
\end{tabular}

2.3 Each meaning of a lemma is presented separately and given a new number. The meanings are ordered according to the frequency with which they occur in Russian. The fact that Russian was chosen does not indicate any superiority - a choice had to be made, due to the constraints of the linear structure of the dictionary. Also, it does not also mean that if a given meaning of a lemma does not occur in Russian, it is not included in the dictionary. The most important meanings in each language for each lemma are presented. If a meaning does not occur in a given language, it is indicated by the phrase brak znaczenia 'the meaning does not occur'. This does not mean, however, that this particular meaning does not occur in the language at all. It only means that the meaning is not encoded in the word that is given as the equivalent of the Russian lemma. If the equivalents for all the meanings of all lemmas in each of the languages were to be included, it would inevitably lead to an infinite number of meanings and definitions, as well as to a potential circularity of description. For the sake of transparency and clarity, the option above was discarded and the formula described earlier was adopted.

2.4 The definitions in the dictionary are composed of simple words. Defining lemmas with their synonyms was avoided. Example phrases and sentences for each meaning of every lemma are provided. The examples come from monolingual national corpora, as well as multilingual parallel corpora. Examples were chosen carefully, so as to fulfil two main purposes: (a) to illustrate typical collocations of a word and (b) to illustrate its grammatical properties, e.g. the valence of a verb, the prepositional and case constraints of adjectives, or the position the word should appear in. The examples often include phrasemes (phrases that are fixed in a given culture but have not become a unit of language yet), sayings and idioms, e.g. abonent czasowo niedostępny for abonent, or Apetyt rośnie w miarę jedzenia for apetyt. 


\section{Types of labels}

There are three types of labels in the dictionary:

3.1 Formal labels: part of speech, grammatical properties (gender, aspect, defective inflectional paradigms), and the subject area of the word.

zaimek [pronoun] eгó I forma $B ., D$. zaimków osobowych он, оно; не́го forma $B ., D$. zaimka osobowego moú; jego I forma $B$., $D$. zaimka osobowego on i $D$. zaimka osobowego ono

przymiotnik [adjective] бе́гл|ый przymiotnik; бе́гъл przymiotnik; pobieżn|y przymiotnik

przystówek [adverb] ава́нсом przystówek; ава́нсово przystówek; awansem przystówek

spójnik [conjunction] éсли spójnik; акó spójnik; jeśli spójnik

partykuta [particle] аво́сь partykuta; дано́ partykuta; a nuż fraza part.

wykrzyknik [interjection] aгá wykrzyknik; axá wykrzyknik; aha wykrzyknik

fraza rzeczownikowa [nominal phrase] белору́чк|a, -и; -и rz. $\dot{z}$. pot. iron.; готова́нк|о, -овци rz. m. pot. iron.; paniczyk $\mathbf{z}$ białymi rączkami | panienka $\mathbf{z}$ białymi rączkami fraza rzeczownikowa

fraza partykutowa [particle phrase] аво́сь partykuta; дано́ partykuta; a nuż fraza part.

vi. [perfective form of a verb] взбега́|ть, -ю, -ешь vi. state, intransitive; изти́чвам, -аш vi. state, intransitive; wbiega|ć, - -m, -sz vi. state, intransitive

$v p$. [imperfective form of a verb] вбить, вобью́, вобьёшь vp. event, transitive; вби́я, -еш vp. event, transitive; wbi|ć, -ję, -jesz vp. event, transitive

l. poj. [singular] апартаме́нт|ы, -ов (pl. tantum) (rzadziej l. poj.)

l. mn. [plural] бъ́деще $r z . n$. bez l. mn.

sg. tantum [singularia tantum] бель|ё, -я́ (sg. tantum) rz. n.; бельо́ (sg. tantum) rz. n.; bielizn|a, -y (sg. tantum) rz. $\dot{z}$.

pl. tantum [pluralia tantum] алиме́нт|ы, -ов (pl. tantum) rz. m.; издръъжка, -и $r z . \dot{z} . ;$ aliment|y, -ów (pl. tantum) rz. mnieżyw.

rz. m. [masculine noun] бе́per, -a, Msc. о -е і на -у; -á $r z . m$.

rz. mnieżyw. [masculine inanimate noun] brzeg, -u; -i rz. mnieżyw.

rz. mos. [masculine personal noun] aferzys|ta, -ty; -ci rz. mos.

rz. mżyw. [masculine animate noun] gol|ąb, -ębia; -ębie rz. mżyw.

rz. $n$. [neuter noun] тарале́ж|че, -та $r z . n$.

$r z . \dot{z}$. [feminine noun] дево́йка $r z$. $\dot{z}$.

$D$. [genetive] де́вушк|a, D. l. mn. -шек $r z . \dot{z}$.

C. [dative] dzięki przyimek z $C$.

$B$. [accusative] душ|á, -и́, B. -y; l. mn. -и $r z . \dot{z}$.

$N$. [ablative] nią forma $N$. zaimka osobowego ona po przyimku $z$

Msc. [locative] аэропо́рт, -а, Msc. в -у́; -ы $r z . m$.

Voc. [vocative] бог, -а, Voc. Бо́же; -и, -о́в $r z . m$.

bot. [botany] ежеви́к|a, -и (sg. tantum) rz. $\dot{z}$. bot.; къпи́н|а, -и rz. $\dot{z}$. bot.; jeżyn|a, -y; -y rz. $\dot{z}$. bot.

zool. [zoology] áист,-а; -ы rz. m. zool.; щъ́ркел, -и; (два) щъ́ркела $r z . m$. zool.; bocian, -а; -y rz. mżyw. zool.

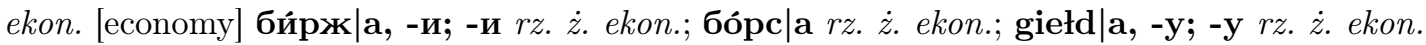
teatr. [theatre] акт, -а; -ы rz. m. teatr.; акт, -ове; (два) а́кта rz. m. teatr.; akt, -u; -у rz. mnieżyw. teatr.

mors. [sailing] бак II, -а; -и rz. m. mors., żegl.; бак, -ове rz. m. mors., żegl.; bak, -u; -a (w zn. 3.); -i rz. mnieżyw. mors., żegl. 
inform. [computer technology] ба́за да́нных fraza rzeczownikowa $\dot{z}$. inform.; ба́за да́нни fraza rzeczownikowa $\dot{z}$. inform.; baza danych fraza rzeczownikowa $\dot{z}$. inform.

prawn. [law] акт, -а; -ы rz. m.; акт, -ове; (два) а́кта rz. m.; akt, -u; -y rz. mnieżyw. med. [medicine] бельм|о́, -á; -а $r z . n$.; перде́ на око́то fraza rzeczownikowa; bielm|o, -a; -ф rz. $n$.

etn. [etnography] ау́л, -а; -ы rz. m. etn.; ау́л, -и; (два) аула rz. m. etn.; auł, -u; -у rz. mnieżyw. etn.

3.2 Semantic labels indicate the stylistic features of words, as well as the meaning of verbs described in accordance with the net theory of time and aspect and the semantic metalanguage developed in Koseska-Toszewa (2006). The net theory stipulates that the form of a verb is either its perfective or imperfective variant, whereas the meaning is a state or a number of states and events that concludes with a state or an event, or a number of events and states that concludes with an event. The definitions of the terms event, state and configuration of events / states are taken from the net model of time and aspect: an event has no temporal duration - it only begins, ends or interrupts states, whereas a state is extended in time and thus has temporal duration ${ }^{1}$. The Petri net theory - crucial for the description of time and aspect - is also a theory with a direct approach to the semantics of natural languages (see Petri, 1962; Mazurkiewicz, 1986; Koseska \& Mazurkiewicz, 1988, 1994).

3.3 Petri nets consist of a finite number of objects that symbolise states and events, which are connected by succession relations. These proceed either from an event to a state (when an event gives rise to a state) or from a state to an event (when a state concludes with an event). A succession relation does not have to proceed in a linear order; some objects in a Petri net might not be comparable in terms of linearity, when none of the objects precedes another object. A state is a feature of an object in the real world. In the discrete approach to process description, the paradigm of a state is its persistence. Every state persists for some time. Two successive states are divided by an event, which gives rise to a new state and concludes the previous state. In general, an event concludes one state and/or gives rise to another. We can conceive of an event as a point on a temporal axis, because being a boundary between two states, it does not have temporal duration (it does not persist in time). To give an example, the four seasons are states, whereas equinoxes and solstices are events - the spring equinox (an event) is a boundary between winter (a state) and spring (a state) (see Petri, 1963; Mazurkiewicz, 1986).

3.4 The differentiation between states and events is a crucial feature of Petri nets. Every event either gives rise to or concludes a state; two successive states must be divided by an event that concludes the first and gives rise to the second. Analogically, a state always comes between two successive events, even if it is a state of the following sort: "one event occurred but another event has not happened yet". Perfective verb forms have two typical meanings: an event (event_1) or a number of states and events that conclude with an event (event_2). Consequently, an imperfective verb form carries one of the two meanings: a state (state_1) or a number of states and events that conclude with a state (state_2). We can illustrate the meanings of states and events with the aspectual and temporal relation, that is when a verb form conveys a given tense in a sentence (our dictionary provides sentences in Bulgarian, Polish and Russian). As far as infinitives are concerned, our dictionary only indicates whether it is an event or a state.

3.5 The semantic category of time is a category that sets states and events against the state of discourse with the use of precedence and succession relations (Koseska-Toszewa, 2006). Since the model is finite, we cannot treat states as sets of events and, consequently, reduce the model to

\footnotetext{
${ }^{1}$ For more information on the application of Petri nets in the description of natural languages see: Mazurkiewicz (1986); Koseska-Toszewa and Mazurkiewicz (1988); Koseska-Toszewa (2006); Koseska-Toszewa and Mazurkiewicz (2010).
} 
events only, as proposed by Reinchenbach (1967). If we try to interpret a state as a set of events, we come up against a number of problems: Which events should we choose? All of them or just a limited number? If it is a limited number, what criteria should we adopt to choose them? On the other hand, if we try to reduce the model only to states, we will be unable to interpret such phenomena as „zderzenie”, „otwarcie”, „odsłonięcie”, „przebudzenie” and so on:

state: гада́|ть, -ю, -ешь vi. state, intransitive; предска́зв|ам, -аш vi. state, intransitive; wróż $\mid \mathbf{y c ́},-\mathbf{e} ;$-ysz vi. state, intransitive

state transitive: аттест|ова́ть, -у́ю, -у́ешь I vi. state, transitive; атести́ра|м, -ш, -ø I vi. state, transitive; opini|ować, -uję, -ujesz vi. state, transitive

event transitive: аттест|ова́ть, -у́ю, -у́ешь II vp. event, transitive; атести́ра|м, -ш, -ø II $v p$. event, transitive; zaopini|ować, -uję, -ujesz vp. event, transitive

\section{Other semantic labels}

przen. [metaphorical] дожд|ь, -я́ rz. m. 2. przen. 'bardzo duża ilość czegoś' На сие́нy nádaem дождъ ивето́в.; дъжд rz. m. 2. przen. 'bardzo duża ilość czegoś' дбжд от ияветя́, метеори́тен дбжд; deszcz, -u; -e rz. m.; 2. przen. 'bardzo duża ilość czegoś' deszcz ztota, prezentów, meteorytów pot. [informal] ба́б|ки, -ок (pl. tantum) rz. $\dot{z}$. pot.; пари́ rz. (pl. tantum); forsa, -y (sg. tantum) rz. $\dot{z}$. pot.

ofic. [formal] акт, -а; -ы rz. m. 1. ofic. 'działanie, czyn (zazwyczaj będący urzeczywistnieniem jakiegoś zamysłu bądź przejawem, wyrazem czegoś)' mеррористи́ческий áкm; áкm до́брой во́ли; полово́ и́ áкm; акт; -ове (два) а́кта rz. m. 1. ofic. 'działanie, czyn (zazwyczaj będący urzeczywistnieniem jakiegoś zamysłu bądź przejawem, wyrazem czegoś)' терористи́чен акт; акт на добра́ во́ля; по́лов акт; akt, -u; -y rz. mnież 1. ofic. 'działanie, czyn (zazwyczaj będący urzeczywistnieniem jakiegoś zamysłu bądź przejawem, wyrazem czegoś)' akt terroru; akt dobrej woli; akt ptciowy; akt koronacji

przestarz. [dated] бухга́лтер rz. m. (m. i $\dot{z}$.$) : счетоводи́тел, -и rz. m.; buchalter, -a; -rzy$ rz.m. przestarz.

hist. [historical] атама́н, -а; -ы rz. m. 1. hist. 'dowódca wojsk i naczelnik osiedli kozackich' Командова́л ру́сским во́йском атама́н Ерма́к.; атама́н, -и rz. m. 1. hist. 'dowódca wojsk i naczelnik osiedli kozackich' Кома́ндвуващ, ру́ските войски́ бе́ше атама́нбт Ерма́к.; ataman, -a; -i rz. mos. 1. hist. 'dowódca wojsk i naczelnik osiedli kozackich' Dowódca wojsk rosyjskich byt ataman Jermak.

pogardl. [derogatory] дед rz. m.; дя́до $r z . n . ;$ dziad, -a; -y; -owie rz. m.; 2. pogardl. 'stary człowiek' Weźcie stad tego dziada, niech tu nie mamrocze.

pejor. [pejorative] ба́ба, -ы; -ы rz. $\dot{z} .2$. pejor. lub lekcew. 'mężczyzna, który jest zbyt delikatny, słaby, nieśmiały' Не будъ ба́бой, пролви́ твёрдость!; жен|а́, -и rz. д̇; 2. pejor. lub lekcew. 'mężczyzna, który jest zbyt delikatny, słaby, nieśmiały' Той се дгржú като́ женá!; bab|a, -y; -y rz. $\dot{z}$. pot. 2. pejor. lub lekcew. 'mężczyzna, który jest zbyt delikatny, słaby, nieśmiały' Ale z niego baba!

wulg. [offensive] е́дк|ий przymiotnik; разя́жд|ащ imiestów czynny; żrący imiestów czynny 3. wulg. 'taki, który żre' (imiesłów od żreć w zn. 'jeść') ̇̇raca świnia 


\section{$5 \quad$ Syntactic labels}

Syntactic labels indicate whether a verb is transitive, intransitive or reflexive. A verb is transitive if it is takes a direct object; in Polish the direct object comes in the accusative case. Conversely, a verb is intransitive if it precludes taking a direct object; in Polish, an intransitive verb takes a noun phrase where a noun is in any case other than the accusative.

transitive: адрес|ова́ть, -ую, -уешь vi. state, transitive; адреси́ра|м, -ш, -ø vi. state, transitive; adres|ować, -uję, -ujesz vi. state, transitive

intransitive: гля|де́ть, -жу́; -ди́шь vi. state, intransitive; гле́дам, -аш vi. state, transitive patrz|eć, patrz|yć, -ę; -ysz vi. state, intransitive

aux: вы́леч|иться, -усь, -ишься vp. event, aux; излеку́вам се vp. event, aux; wylecz|ус́ się, -ę, -ysz vp. event, aux

\section{Conclusions}

In the $21^{\text {st }}$ century, we face two great challenges: making academic research more interdisciplinary and building an integrated multinational European community. We hope that our dictionary will help address these challenges by promoting multilingualism and facilitating intercultural communication. The primary language of the dictionary is Polish - the largest Slavic language in the European Union. The target audience of the dictionary are speakers of Polish, both in Poland and all around the world: experts in Slavic languages, scholars, lexicographers, encyclopaedia writers, students, etc.

We see the dictionary as an innovation in lexicography, because its open structure enables more languages to be added in the future, including non-Slavic languages. Developed with the use of the most recent methodologies available, the dictionary will constitute a sound basis for lexicographic research in the future, in particular for the development on multilingual electronic dictionaries.

What sets the dictionary apart from other dictionaries is that it ventures beyond the standard vocabulary one might expect from a dictionary of this sort. Leksykon... also contains neologisms as well as realogisms - words which often do not have perfect equivalents in other languages, because they are so deeply embedded in a nation's culture. Each entry in the dictionary offers state-of-the-art semantic and syntactic labels, developed by Polish experts in Slavic semantics and aspectology.

During the Polish presidency of the EU, a conference entitled Multilingual Competences for Professional and Social Success in Europe was held. It concluded with the following declaration: "Multilingualism is not only part of European heritage, but also a chance to develop a society which is open, respectful of cultural diversity and ready for cooperation". However, the chief obstacles that prevents the EU from attaining the full integration of its economies and societies are language barriers. This dictionary will help overcome these barriers by promoting Slavic languages.

\section{References}

Bulgarian National Corpus, IBE BAN. (n.d.). Retrieved 12 October 2015, from http://search.dcl.bas . $\mathrm{bg} /$.

Dimitrova, L. \& Koseska-Toszewa, V. (2009a). Bulgarian-Polish Corpus. Cognitive Studies / Études cognitives, (9), 133-141.

Dimitrova, L. \& Koseska-Toszewa, V. (2009b). Classifiers and digital dictionaries. Cognitive Studies / Études cognitives, (9), 117-131. 
Dimitrova, L. \& Koseska-Toszewa, V. (2012). Bulgarian-Polish Parallel Digital Corpus and quantification of time. Cognitive Studies / Études cognitives, (12), 199-207. DOI: http://dx.doi.org/10.11649/ cs. 2012.013

Dimitrova, L. \& Koseska-Toszewa, V. (2014). Semantics properties of selected universal language categories in digital bilingual resources. Sofia: DOVIRA Publ. House.

Dimitrova, L., Koseska-Toszewa, V., \& Satoła-Staśkowiak, J. (2009). Towards a unification of the classifiers in dictionary entry. In R. Garabík (Ed.), Metalanguage and Encoding Scheme Design for Digital Lexicography: Proceedings of the MONDILEX Third Open Workshop, 15-16 April, 2009, Bratislava, Slovakia (pp. 48-58). Bratislava: L'. Štúr Institute of Linguistic, Slovak Academy of Sciences.

Dimitrova, L., Koseska-Toszewa, V., \& Satoła-Staśkowiak, J. (2012). Neologisms in bilingual digital dictionaries (on the example of Bulgarian-Polish Dictionary). Cognitive Studies / Études cognitives, (12), 107-114. DOI: http://dx.doi.org/10.11649/cs.2012.008

Garabík, R., Dimitrova, L., \& Koseska-Toszewa, V. (2011). Web-presentation of bilingual corpora (SlovakBulgarian and Bulgarian-Polish). Cognitive Studies / Études cognitives, (11), 227-239. DOI: http: //dx.doi.org/10.11649/cs.2011.014

Kisiel, A., Satoła-Staśkowiak, J., \& Sosnowski, W. (2014). The need for an electronic multilingual dictionary. Cognitive Studies / Études cognitives, (14), 55-64. http://doi.org/10.11649/cs.2014.006

Kisiel, A., Satoła-Staśkowiak, J., \& Sosnowski, W. (2014). О работе над многоязычным словарем. In Прикладна лінгвістика та лінгвістичні технологї, MegaLing-2013: Зб. наук. пр. (pp. 112-120). Київ: Національна академія наук України, Український мовно-інформаційний фонд.

Koseska-Toszewa, V. (1974). Z problematyki temporalno-aspektowej w języku bułgarskim (Relacja imperfectum - aoryst). Studia z Filologii Polskiej i Stowiańskiej, 14, 213-226.

Koseska-Toszewa, V. (2006). Gramatyka konfrontatywna bułgarsko-polska (Vol. 7, Semantyczna kategoria czasu). Warszawa: Slawistyczny Ośrodek Wydawniczy.

Koseska-Toszewa, V. \& Mazurkiewicz, A. (1988). Net representation of sentences in natural languages. In Advances in Petri Nets 1988 (pp. 249-266). Berlin: Springer-Verlag. (Lecture Notes in Computer Science, 340). http://dx.doi.org/10.1007/3-540-50580-6_32

Koseska-Toszewa, V. \& Mazurkiewicz, A. (1994). Description a l'aide de reseaux de la temporalite et modalite dans la phrases dans la langue naturelle. In Cognitive Studies / Études cognitives, 1 (pp. 89-112), Warszawa.

Koseska-Toszewa, V. \& Mazurkiewicz, A. (2010). Time flow and tenses. Warszawa: Slawistyczny Ośrodek Wydawniczy.

Koseska-Toszewa, V. \& Satoła-Staśkowiak, J. (2013). O pracy nad słownikami książkowymi i elektronicznymi z językiem bułgarskim. In Сборник с материали от Шестата национална конференция с международно участие по лексикография и лексикология. (70 години българска академична лексикография, София, 24-25 октомври 2012). София: АИ Проф. „М. Дринов“.

Koseska-Toszewa, V. \& Sosnowski, W. (2015). Multilingualism and dictionaries. Cognitive Studies / Études cognitives, (15), 43-55. http://dx.doi.org/10.11649/cs.2015.004.

Koseska-Toszewa, V., Korytkowska, M., \& Roszko, R. (2007). Polsko-bułgarska gramatyka konfrontatywna. Warszawa: Wydawnictwo Akademickie Dialog.

Koseska-Toszewa, V., Satoła-Staśkowiak, J., \& Duszkin, M. (2012). Теоретические и методологические аспекты создания польско-болгарско-русского словаря. In MegaLing'2011: Горизонти прикладної лінгвістики і лінгвістичних технологій (рp. 210-219). Київ: Національна академія наук України, Український мовно-інформаційний фонд.

Lekov, I. \& Sławski, F. (Eds.). (1961). Полско-български речник. София: БАН.

Mazurkiewicz, A. (1986). Zdarzenia i stany: elementy temporalności. In V. Koseska-Toszewa, I. Sawicka, \& J. Mindak (Eds.), Studia gramatyczne bułgarsko-polskie (Vol. 1, Temporalność, pp. 7-21). Wrocław: Ossolineum.

Petri, C.A., (1962). Fundamentals of the Theory of Asinchronious Information Flow, In Proc. of IFIP'62 Congress, North Holland Publ. Comp., Amsterdam.

Reichenbach, H. (1967). Analiza języka potocznego, In Logika i język (p. 148), Warszawa.

Satoła-Staśkowiak, J. (2013a). Contemporary contrastive studies of Polish, Bulgarian and Russian neologisms versus Language Corpora. Cognitive Studies / Études cognitives, (13), 143-160.

Satoła-Staśkowiak, J. (2013b). Neologizmy bułgarskie, polskie i rosyjskie w ujęciu konfrontatywnym. In Проблеми на неологията в славянските езици. (рр. 21-30). София: БАН. 
Satoła-Staśkowiak, J. (2013c). Polskie i bułgarskie neologizmy znaczeniowe. In Проблеми на неологията в славянските езичи (рр. 218-230). София: БАН.

Satoła-Staśkowiak, J. \& Koseska-Toszewa, V. (with Dimitrova, L.). (2014). Współczesny słownik bułgarsko-polski (Pt. 1). Warszawa: Slawistyczny Ośrodek Wydawniczy.

Sławski, F. (1987). Podręczny słownik bułgarsko-polski z suplementem. Warszawa: Państwowe Wydawnictwo Wiedza Powszechna.

Андрейчин, Л., Георгиев, Л., Илчев, С., Костов, Н., Леков, И., Стойков, С., \& Тодоров, Ц. (1973). Български тълковен речник (3rd ed.). София: Наука и изкуство.

Буров, С., Бонджолова, В., Илиева, М., \& Пехливанова, П. (1999/2000). Съвременен тълковен речник на български език с приложения (3rd ed.). Велико Търново: Gaberoff.

Леков, И. (1945). Полско-български речник. София: БАН.

Пернишка, Е., Благоева, Д., \& Колковска, С. (2010). Речник на новите думи в българския език $\left(1^{\text {st }}\right.$ ed.). София: Наука и изкуство.

\section{References (Transliteration)}

Andreı̆chin, L., Georgiev, L., Ilchev, S., Kostov, N., Lekov, I., Sto1̌kov, S., \& Todorov, T. (1973). Bǔlgarski tŭlkoven rechnik (3rd ed.). Sofiia: Nauka i izkustvo.

Bulgarian National Corpus, IBE BAN. (n.d.). Retrieved October 12, 2015, from http://search.dcl. bas.bg/

Burov, S., Bondzholova, V., Ilieva, M., \& Pekhlivanova, P. (1999/2000). Süvremenen tŭlkoven rechnik na bŭlgarski ezik s prilozheniia (3rd ed.). Veliko Tŭrnovo: Gaberoff.

Dimitrova, L. \& Koseska-Toszewa, V. (2009a). Bulgarian-Polish Corpus. Cognitive Studies / Études cognitives, (9), 133-141.

Dimitrova, L. \& Koseska-Toszewa, V. (2009b). Classifiers and digital dictionaries. Cognitive Studies / Études cognitives, (9), 117-131.

Dimitrova, L. \& Koseska-Toszewa, V. (2012). Bulgarian-Polish Parallel Digital Corpus and quantification of time. Cognitive Studies / Études cognitives, (12), 199-207. DOI: http://dx.doi.org/10.11649/ cs. 2012.013

Dimitrova, L. \& Koseska-Toszewa, V. (2014). Semantics properties of selected universal language categories in digital bilingual resources. Sofia: DOVIRA Publ. House.

Dimitrova, L., Koseska-Toszewa, V., \& Satoła-Staśkowiak, J. (2009). Towards a unification of the classifiers in dictionary entry. In R. Garabík (Ed.), Metalanguage and Encoding Scheme Design for Digital Lexicography: Proceedings of the MONDILEX Third Open Workshop, 15 - 16 April, 2009, Bratislava, Slovakia (pp. 48-58). Bratislava: L'. Štúr Institute of Linguistic, Slovak Academy of Sciences.

Dimitrova, L., Koseska-Toszewa, V., \& Satoła-Staśkowiak, J. (2012). Neologisms in bilingual digital dictionaries (on the example of Bulgarian-Polish Dictionary). Cognitive Studies / Études cognitives, (12), 107-114. DOI: http://dx.doi.org/10.11649/cs.2012.008

Garabík, R., Dimitrova, L., \& Koseska-Toszewa, V. (2011). Web-presentation of bilingual corpora (SlovakBulgarian and Bulgarian-Polish). Cognitive Studies / Études cognitives, (11), 227-239. DOI: http: //dx.doi.org/10.11649/cs.2011.014

Kisiel, A., Satoła-Staśkowiak, J., \& Sosnowski, W. (2014). O rabote nad mnogoiazychnym slovarem. In Prykladna linhvistyka ta linhvistychni tekhnolohï, MegaLing-2013: Zb. nauk. pr. (pp. 112-120). Kyïv: Natsional'na akademiia nauk Ukraïny, Ukraïns'kyı̌ movno-informatsiünyı̆ fond.

Kisiel, A., Satoła-Staśkowiak, J., \& Sosnowski, W. (2014). The need for an electronic multilingual dictionary. Cognitive Studies / Études cognitives, (14), 55-64. http://doi.org/10.11649/cs.2014.006

Koseska-Toszewa, V. (1974). Z problematyki temporalno-aspektowej w języku bułgarskim (Relacja imperfectum - aoryst). Studia z Filologii Polskiej i Stowiańskiej, 14, 213-226.

Koseska-Toszewa, V. (2006). Gramatyka konfrontatywna bułgarsko-polska (Vol. 7, Semantyczna kategoria czasu). Warszawa: Slawistyczny Ośrodek Wydawniczy.

Koseska-Toszewa, V. \& Mazurkiewicz, A. (1988). Net representation of sentences in natural languages. In Advances in Petri Nets 1988 (pp. 249-266). Berlin: Springer-Verlag. (Lecture Notes in Computer Science, 340). http://dx.doi.org/10.1007/3-540-50580-6_32

Koseska-Toszewa, V. \& Mazurkiewicz, A. (1994). Description a l'aide de reseaux de la temporalite et modalite dans la phrases dans la langue naturelle. In Cognitive Studies / Études cognitives, (1) (pp. 89-112), Warszawa. 
Koseska-Toszewa, V. \& Mazurkiewicz, A. (2010). Time flow and tenses. Warszawa: Slawistyczny Ośrodek Wydawniczy.

Koseska-Toszewa, V. \& Satoła-Staśkowiak, J. (2013). O pracy nad słownikami książkowymi i elektronicznymi z językiem bułgarskim. In Sbornik s materiali ot Shestata natsionalna konferentsiia $s$ mezhdunarodno uchastie po leksikografiia i leksikologiia (70 godini bŭlgarska akademichna leksikografiia, Sofiia, 24-25 oktomvri 2012). Sofiia: AI "Prof. M. Drinov".

Koseska-Toszewa, V. \& Sosnowski, W. (2015). Multilingualism and dictionaries. Cognitive Studies / Études cognitives, (15), 43-55. http://dx.doi.org/10.11649/cs.2015.004

Koseska-Toszewa, V., Korytkowska, M., \& Roszko, R. (2007). Polsko-bułgarska gramatyka konfrontatywna. Warszawa: Wydawnictwo Akademickie Dialog.

Koseska-Toszewa, V., Satoła-Staśkowiak, J., \& Duszkin, M. (2012). Teoreticheskie i metodologicheskie aspekty sozdaniia pol'sko-bolgarsko-russkogo slovaria. In MegaLing'2011: Horyzonty prykladnö̈ linhvistyky i linhvistychnykh tekhnolohiǔ (pp. 210-219). Kyïv: Natsional'na akademiia nauk Ukraïny, Ukraïns'kyı̆ movno-informatsiunny̌ fond.

Lekov, I. (1945). Polsko-bŭlgarski rechnik. Sofiia: BAN.

Lekov, I., \& Sławski, F. (Eds.). (1961). Polsko-bŭlgarski rechnik. Sofiia: BAN.

Mazurkiewicz, A. (1986). Zdarzenia i stany: elementy temporalności. In V. Koseska-Toszewa, I. Sawicka, \& J. Mindak (Eds.), Studia gramatyczne bułgarsko-polskie (Vol. 1, Temporalność, pp. 7-21). Wrocław: Ossolineum.

Petri, C.A., (1962). Fundamentals of the Theory of Asinchronious Information Flow, In Proc. of IFIP'62 Congress, North Holland Publ. Comp., Amsterdam.

Reichenbach, H. (1967). Analiza języka potocznego, In Logika i język (p. 148), Warszawa.

Pernishka, E., Blagoeva, D., \& Kolkovska, S. (2010). Rechnik na novite dumi v bŭlgarskiia ezik (1 ${ }^{\text {st }}$ ed.). Sofiia: Nauka i izkustvo.

Satoła-Staśkowiak, J. (2013a). Contemporary contrastive studies of Polish, Bulgarian and Russian neologisms versus Language Corpora. Cognitive Studies / Études cognitives, (13), 143-160.

Satoła-Staśkowiak, J. (2013b). Neologizmy bułgarskie, polskie i rosyjskie w ujęciu konfrontatywnym. In Problemi na neologiiata v slavianskite ezitsi. (pp. 21-30). Sofiia: BAN.

Satoła-Staśkowiak, J. (2013c). Polskie i bułgarskie neologizmy znaczeniowe. Problemi na neologiiata $v$ slavianskite ezitsi. (pp. 218-230). Sofiia: BAN.

Satoła-Staśkowiak, J. \& Koseska-Toszewa, V. (with Dimitrova, L.). (2014). Współczesny słownik bułgarsko-polski (Pt. 1). Warszawa: Slawistyczny Ośrodek Wydawniczy.

Sławski, F. (1987). Podręczny stownik butgarsko-polski z suplementem. Warszawa: Państwowe Wydawnictwo Wiedza Powszechna.

\section{Acknowledgment}

This work was supported by a core funding for statutory activities from the Polish Ministry of Science and Higher Education.

The authors declare that they have no competing interests.

The authors' contribution was as follows: concept of the study: Wojciech Sosnowski, Violetta Koseska-Toszewa, Anna Kisiel; data analyses: Wojciech Sosnowski, Violetta Koseska-Toszewa, Anna Kisiel; the writing: Wojciech Sosnowski, Violetta Koseska-Toszewa, Anna Kisiel.

This is an Open Access article distributed under the terms of the Creative Commons Attribution 3.0 PL License (http://creativecommons.org/licenses/by/3.0/pl/), which permits redistribution, commercial and noncommercial, provided that the article is properly cited.

(C) The Authors 2016

Publisher: Institute of Slavic Studies, Polish Academy of Sciences, University of Silesia \& The Slavic Foundation 